\title{
Endoscopic-assisted posterior interhemispheric retrocallosal transfalcine approach for microsurgical resection of a pineal region falcotentorial meningioma: operative video and technical nuances
}

\author{
James K. Liu, MD, and Michael A. Cohen, MD \\ Department of Neurological Surgery, Center for Skull Base and Pituitary Surgery, Neurological Institute of New Jersey, Rutgers \\ New Jersey Medical School, Newark, New Jersey \\ Falcotentorial meningiomas are rare tumors of the pineal region that arise from the dural folds where the falx and \\ tentorium meet and are often intimately related to the vein of Galen and straight sinus. These lesions often present with \\ signs and symptoms related to hydrocephalus and brainstem compression. Surgical resection of falcotentorial meningio- \\ mas remains the definitive treatment, with a variety of surgical approaches used to resect these lesions. The choice of \\ approach depends on several factors, including the size and location of the tumor relative to the vein of Galen complex. \\ Falcotentorial meningiomas can be technically challenging to remove with significant risk of morbidity because of the \\ close proximity to and occasional invasion of the vein of Galen and straight sinus. In this operative video, the authors \\ demonstrate an illustrative step-by-step technique for endoscopic-assisted microsurgical resection of a falcotentorial me- \\ ningioma using the posterior interhemispheric retrocallosal transfalcine approach for a superiorly positioned falcotento- \\ rial meningioma. The surgical nuances are discussed, including the surgical anatomy, gravity-assisted interhemispheric \\ approach in the lateral position, retrocallosal dissection, transfalcine exposure, tumor removal, and preservation of the \\ vein of Galen complex. In summary, the posterior interhemispheric retrocallosal transfalcine approach is a useful surgi- \\ cal strategy for select superiorly positioned falcotentorial meningiomas.
}

The video can be found here: https://youtu.be/d8mdunsRacs.

KEYWORDS posterior interhemispheric retrocallosal transfalcine approach; endoscopic-assisted microsurgery; falcotentorial meningioma; pineal region tumor; operative video; technical nuances; video

SUBMITTED August 31, 2015. ACCEPTED October 14, 2015.

INCLUDE WHEN CITING Published online January 1, 2016; DOI: http://thejns.org/doi/abs/10.3171/2016.1.FocusVid.15453.

CORRESPONDENCE James K. Liu, MD, Department of Neurological Surgery, Rutgers University, New Jersey Medical School, 90 Bergen Street, Suite 8100, Newark, New Jersey 07103. email: james.liu.md@rutgers.edu. 